\title{
Ascites: it is not all alcohol-a case of constrictive pericarditis
}

\author{
Asgher Champsi, ${ }^{1}$ Muzzammil $\mathrm{Ali}^{2}$
}

${ }^{1}$ University Hospital Birmingham NHS Foundation Trust, Birmingham, UK ${ }^{2}$ Heart of England Foundation Trust, Birmingham, UK

\section{Correspondence to} Dr Asgher Champsi, asgher. champsi@nhs.net

Accepted 27 September 2016

\section{DESCRIPTION}

A 43-year-old man was referred to a specialised liver unit with progressive abdominal distension and sarcopoenia. He had a background of moderate-to-high alcohol intake. His exercise tolerance was appropriate for his age, and he denied having had exertional dyspnoea or orthopnoea. On examination, there was shifting-dullness of his abdomen, bilateral pitting oedema, an elevated jugular venous pressure and sarcopenia. Other than having clinical ascites, there were no stigmata of liver disease. His observations were stable, and urine output acceptable.

His blood tests revealed an acute derangement in his transaminases. A full liver screen was unremarkable in revealing a possible aetiology for this derangement. An abdominal ultrasound scan showed a large amount of ascites, in the presence of a normal liver morphology and patent hepatic vessels. His chest X-ray and ECG (figure 1) were unremarkable. Ascitic fluid demonstrated a transudative picture with a high serum-ascites albumin gradient; samples were negative for tuberculosis or malignancy.

To establish cardiac ventricular function, a transthoracic echocardiogram (TTE) was performed. This showed normal right ventricular dimensions with good systolic function, a mildly dilated right atrium and left ventricular ejection fraction (LVEF) of $57 \pm 5 \%$. A subsequent CT Thorax (figure 2) and cardiac-MRI revealed features in keeping with constrictive pericarditis (figure 3) (video 1). Invasive haemodynamic evaluation during cardiac catheterisation confirmed this diagnosis.

An uneventful surgical pericardiectomy was performed, with no postoperative complications. A repeated TTE 2 weeks postoperatively demonstrated good biventricular function; LVEF was $85 \%$. Histology demonstrated end stage, chronic fibrosing ('obliterative') pericarditis with no

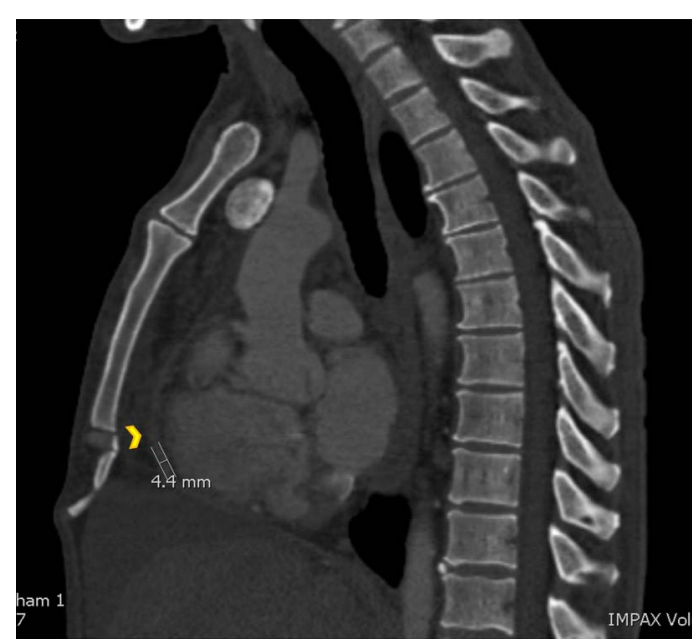

Figure 2 CT Thorax, sagittal section, showing a mildly thickened pericardium 'without' calcification.

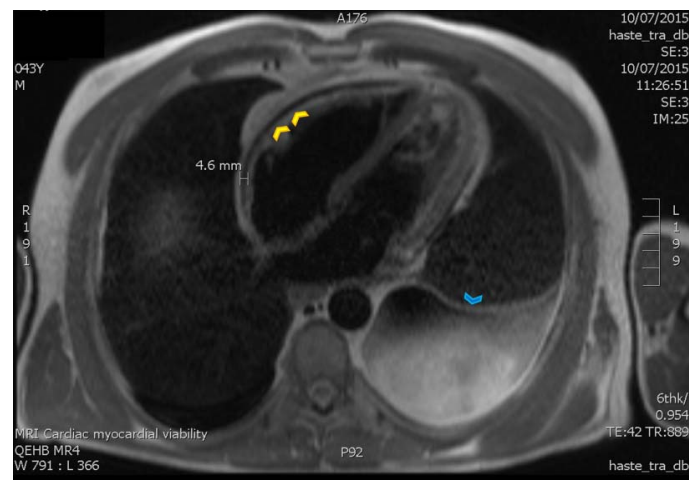

Figure 3 Cardiac MRI axial cut showing a thickened pericardium (normal $<4 \mathrm{~mm}$ ) and a moderate left-sided pleural effusion.
To cite: Champsi A, Ali M. BMJ Case Rep Published online: [please include Day Month Year] doi:10.1136/ bcr-2016-215021

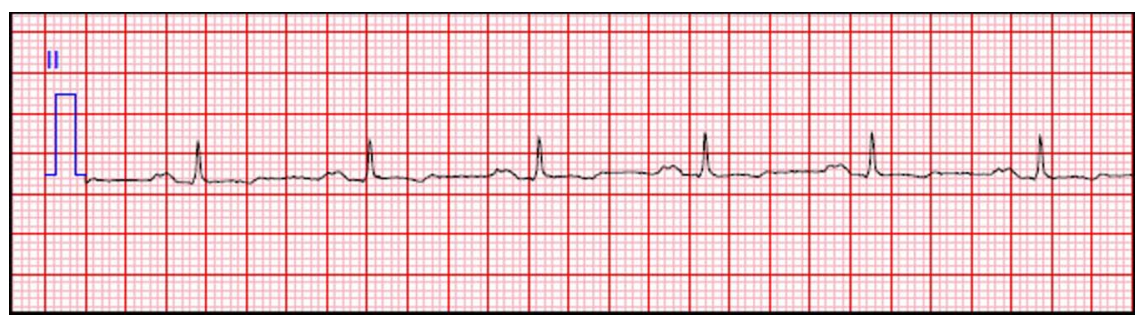

Figure 1 ECG initially seemed unremarkable- on retrospect, non-specific signs of constriction can be noted on the rhythm strip shown, including low-voltage notched P-waves and flattened T-waves. 


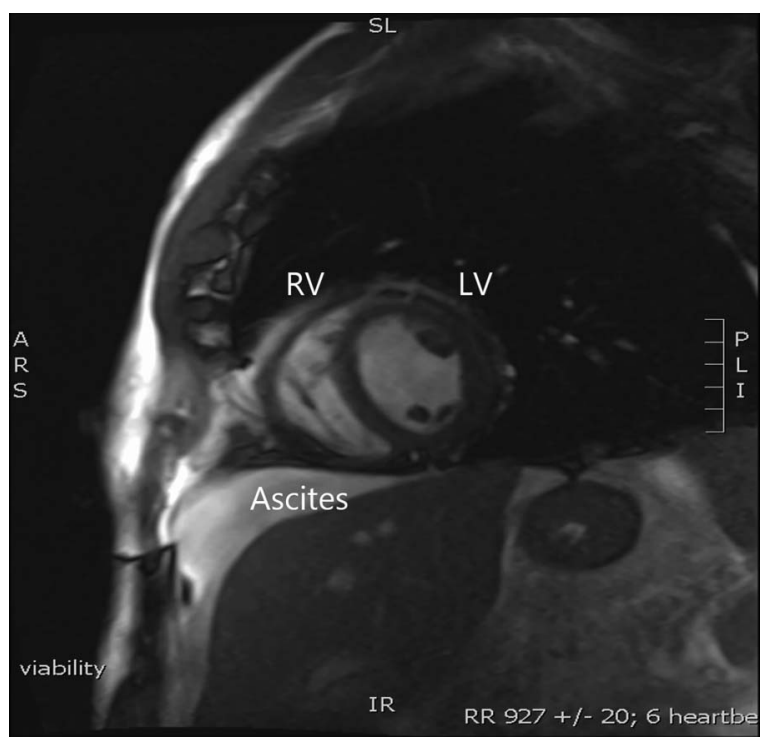

Video 1 These collated images from the patient's cardiac MRI show a diastolic septal bounce due to abrupt cessation of ventricular filling within a non-compliant pericardium.

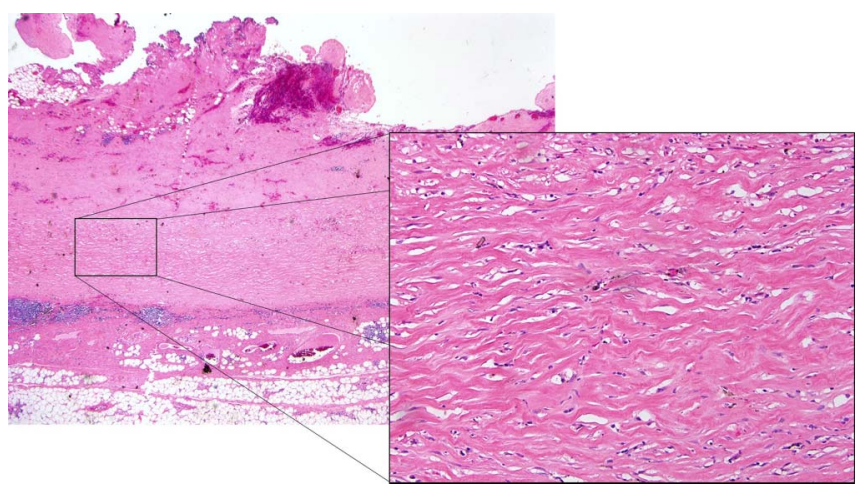

Figure 4 Histology demonstrated extreme hyalosclerotic fibrous thickening of the pericardium. High-power magnifications show a dense, hypovascular, paucicellular plaque-like morphology with widespread 'basket-weave' interstices.

evidence of neoplasia (figure 4). The patient remained without ascites recurrence at 6 months.

Contributors $\mathrm{AC}$ was involved in the diagnostic process, gained consent from the patient, gathered the clinical information for the case, including the compilation of

\section{Learning points}

- Constrictive pericarditis occurs as a result of scarring and consequent loss of the normal elasticity of the pericardial sac. ${ }^{1}$ It can occur after any pericardial disease process, but often following acute pericarditis (viral or idiopathic), or cardiac surgery. ${ }^{2}$ The vast majority of patients with constrictive pericarditis display elevated jugular venous pressure on physical examination. Other important but less common features include pulsus paradoxus, Kussmaul's sign and pericardial knock. Patients also present to hepatology units with peripheral oedema, ascites and/or sarcopeniahighlighting the significance of considering a wider differential in the investigation of ascites.

- Patients with suspected constrictive pericarditis should undergo an initial evaluation with an ECG, chest X-ray and transthoracic echocardiogram. If the diagnosis is uncertain or surgical intervention is planned, additional investigation is often required. This includes cardiac-MRI and/or cardiac catheterisation.

- Pericardiectomy is the only definitive treatment option for patients with symptomatic constrictive pericarditis. ${ }^{3}$ Medical therapy (eg, diuretics) may be used as a temporising measure and for patients who are not candidates for surgery.

images and video, and assisted with the write up of the case. MA critically reviewed the article for intellectual content, performed a review of the literature, interpreted the content for learning points, and assisted with the write up of the case. AC and MA were involved with the conception and design of the manuscript, and approval of the version of the manuscript to be published.

Competing interests None declared.

Patient consent Obtained.

Provenance and peer review Not commissioned; externally peer reviewed.

\section{REFERENCES}

1 Troughton RW, Asher CR, Klein AL. Pericarditis. Lancet 2004;363:717-27.

2 Authors/Task Force MembersAdler Y, Charron P, Imazio M, et al. 2015 ESC Guidelines for the diagnosis and management of pericardial diseases: the Task Force for the Diagnosis and Management of Pericardial Diseases of the European Society of Cardiology (ESC) Endorsed by: the European Association for Cardio-Thoracic Surgery (EACTS). Eur Heart J 2015;36:2921-64

3 Chowdhury UK, Subramaniam GK, Kumar AS, et al. Pericardiectomy for constrictive pericarditis: a clinical, echocardiographic, and hemodynamic evaluation of two surgical techniques. Ann Thorac Surg 2006;81:522-9.

Copyright 2016 BMJ Publishing Group. All rights reserved. For permission to reuse any of this content visit

http://group.bmj.com/group/rights-licensing/permissions.

BMJ Case Report Fellows may re-use this article for personal use and teaching without any further permission.

Become a Fellow of BMJ Case Reports today and you can:

- Submit as many cases as you like

- Enjoy fast sympathetic peer review and rapid publication of accepted articles

- Access all the published articles

- Re-use any of the published material for personal use and teaching without further permission

For information on Institutional Fellowships contact consortiasales@bmjgroup.com

Visit casereports.bmj.com for more articles like this and to become a Fellow 